\title{
Improving Urban Residents' Awareness of the Impact of Household Activities on Climate Change in Lagos State, Nigeria
}

\author{
Olayinka C. Oloke ${ }^{1}$, Kolawole C. Ijasan ${ }^{1}$, Ayodeji O. Ogunde ${ }^{2}$, Lekan M. Amusan ${ }^{2} \&$ Patience F. Tunji-Olayeni ${ }^{2}$ \\ ${ }^{1}$ Department of Estate Management, School of Environmental Sciences College of Science and Technology, \\ Covenant University, Ota, Ogun State, Nigeria \\ ${ }^{2}$ Department of Building Technology, School of Environmental Sciences College of Science and Technology, \\ Covenant University, Ota, Ogun State, Nigeria \\ Correspondence: Olayinka C. Oloke, Department of Estate Management, School of Environmental Sciences \\ College of Science and Technology, Covenant University, Ota, Ogun State, Nigeria. Tel: 234-070-3224-4140. \\ E-mail: c_yinkaoloke@yahoo.com
}

Received: September 10, 2012 Accepted: February 11, 2013 Online Published: March 21, 2013

doi:10.5539/jsd.v6n4p56

URL: http://dx.doi.org/10.5539/jsd.v6n4p56

\begin{abstract}
Climate change is much discussed among professionals, academics, governments, local and international organisations. It is a phenomenon that is increasingly gaining attention because of its negative impacts on human, and natural environments and the economy. Human activities exacerbate climate change and this in turn impacts on livelihood and environment. Urban activities such as transportation and building (household) related activities increase atmospheric concentration of greenhouse gases. Other activities that contribute to greenhouse gas emission include change of land use, removal of land cover, use of fertilizer, pollution of water bodies, deforestation, industrialization, urbanization and poor municipal waste management. However, it is quite unclear whether urban residents have adequate awareness and understanding of what the phenomenon entails and how their daily activities impact atmospheric greenhouse gases' concentration. To this end, questionnaires were distributed to 600 households selected from three local government areas in Lagos State. Data gathered were analysed and presented using tables, percentages, pie and multiple bar charts. Result of analysis indicate that although most urban residents indicate various level of awareness of occurrence, they are least aware of the contribution of household activities to atmospheric greenhouse gas concentration and that professional property managers hardly sensitize occupants in this direction. The study concludes by suggesting ways to call the attention of urban residents to the impact of household activities on atmospheric greenhouse gases' concentration with a view to reducing emission from this sector in the future.
\end{abstract}

Keywords: climate change, urban residents, household activities, property managers

\section{Introduction}

Climate change has emerged as one of the most devastating phenomenon that threatens both human and natural environments. The United Nations Framework Convention on Climate Change (UNFCCC) defines climate change as a change of climate which is attributable directly or indirectly to human activities that alter the composition of the global atmosphere and which are in addition to natural climate variability observed over a comparable time period (Intergovernmental Panel on Climate Change [IPCC], 2001). According to Odjugo (2011), climate change is caused by both natural (bio-geographical) processes and human (anthropogenic) activities. The author further identified natural processes as (i) astronomical factors such as the eccentricity of earth's orbit, obliquity of ecliptic and orbital procession; and (ii) extraterrestrial factors such as the quality and quantity of solar radiation as well as volcanic eruptions. Li (2009) observed that up to 1950, natural factors particularly solar radiation variations and volcanic dust was the predominated factor of temperature change. However, recent studies have shown that the heightened incidence of climate change across the globe is as a result of aggressive and unsustainable human activities which take place on domestic and industrial scale. The quantum of energy consumed and harmful gases released from these activities have been identified as a major factor accelerating atmospheric global warming in recent times. The IPCC Working Group III, (2007) asserted that global greenhouse gas (GHG) release via human activities have increased by $70 \%$ from 1970 to 2004 . 
Cities consume as much as 80 percent of energy production worldwide and account for a roughly equal share of global greenhouse gas emissions (World Bank Report [WBR], 2010). The report further noted that as development proceeds, greenhouse gas emissions are driven less by industrial activities and more by the energy services required for lighting, heating, and cooling. The International Energy Agency (IEA, 2008) estimates that urban areas currently account for over 67 percent of energy-related global greenhouse gases, which is expected to rise to 74 percent by 2030 . The Agency further estimated that 89 percent of the increase in $\mathrm{CO}_{2}$ from energy use will be from developing countries. According to Energy Information Administration (EIA, 2003), energy use in the building sector in most countries represents about one-third of the total energy consumption while residential building sector accounts for more than half of the electricity consumption in most developing countries in the Organisation for Economic Co-operation and Development (OECD) economies (Synnefa, Santamouris, \& Akbari, 2007). With the rapid rate of urbanization and population growth in the developing countries, building and household related activities in urban is set to surpass all other sectors in greenhouse gases' emission in the foreseeable future unless drastic steps are taken to curb the trend.

However, studies have revealed that there are some misconception and misunderstanding that people hold about climate change in terms of causality, consequences and cures (Boyes \& Stanisstreet, 1998, 1992; Dove, 1996; Rye et al., 1997). These misconceptions according to Aladag and Ugurlu (2009) are probably due to, among other things, the complexity of the science involved, the uncertainties and controversies surrounding them. According to Ekpoh and Ekpoh (2011), climate change specialists have repeatedly pointed out that a solution to climate change problem will require climate change awareness and its proper understanding. Madzwamuse (2010) stated that climate change is both a global and local problem, the intervention of which requires the engagement of stakeholders at global, national and local levels. With a view to improving awareness of urban residents, there is an urgent need to sensitise urban populace on the contribution of household activities to greenhouse gas emission. This study achieves this by examining Lagos State residents' awareness and understanding of the causes and consequences of climate change and how household activities affect the dynamics of the phenomenon.

\section{Literature Review}

\subsection{Urbanization and Population Growth in Developing Countries}

Urbanisation has been identified as one of the most powerful and visible anthropogenic forces on earth (Dawson et al., 2006; United Nations Habitat Report, 2011). It is a process and outcome of social changes, in-flow and concentration of people and activities in cities (Adeniji \& Ogundiji, 2009). The dynamics of the process is driven by changes in population, employment opportunities associated with industrialization, consumption patterns, international migration and accessibility (Dawson et al., 2006). Urban areas account for less than three percent of the earth's land surface but over fifty percent of the world's population (United Nation [UN], 2001; Balk et al., 2004). It is estimated that the total population of cities in developing countries will double between 2000 and 2030 (UN, 2004a, 2004b) but their built-up areas will triple from approximately 200,000sqkm to approximately 600,000 sqkm (Dodman, 2009). Dodman (2009) also asserts that in industrialized countries, the population of cities will increase by approximately 20 percent whilst their built up areas will increase by 2.5 times from approximately $200,000 \mathrm{sqkm}$ to approximately $500,000 \mathrm{sqkm}$. Since the industrial revolution, urban centres have concentrated industries, construction, transportation, households and other activities that release large quantities of GHGs (UN-Habitat, 2011). The increasing concentration of population and economic activities in urban centres demands that more land be developed for public infrastructure (e.g. roads, water facilities and utilities), housing industrial and commercial uses (Adeniji \& Ogundiji, 2009). This has resulted in rapid rate of uncontrolled and unplanned spatial growth forcing millions of people to live in substandard and sub-human environments plagued by slum and grossly inadequate social facilities (Adeniji \& Ogundiji, 2009). Consequently, aggregate urban populace and household activities have drastically increased and by implication, increasing GHG emission and urban vulnerability to climate change hazards.

\subsection{Human-Induced Global Warming/Climate Change}

Anthropogenic activities alter temperature balance of the atmosphere in two ways. First, through the burning of fossil fuel which releases greenhouse gases (GHGs) into the atmosphere; and second through destruction of forest and pollution of water bodies which reduce nature's capacity for absorbing excess GHGs significantly the carbon-dioxide $\left(\mathrm{CO}_{2}\right)$. The Fourth Assessment Report of the IPCC (2007) shows that most of the apparent increase in global temperature since the mid-20th century is due to rise in the level of greenhouse gases which traps infrared radiation. The "greenhouse effect" is a natural phenomenon in which atmospheric gases trap some of the incoming solar energy, thereby making the surface of the planet a habitable spherical island within the 
cold and desolate environment of space (Mills, Lecomte, \& Peara, 2001; UN-habitat, 2011). Greenhouse gases that exist naturally include water vapour $\left(\mathrm{H}_{2} \mathrm{O}\right)$, carbon dioxide $\left(\mathrm{CO}_{2}\right)$, ozone $\left(\mathrm{O}_{3}\right)$, methane $\left(\mathrm{CH}_{4}\right)$, and nitrous oxide $\left(\mathrm{N}_{2} \mathrm{O}\right)$ (UNEP/GRID, 2000 cited in Mills et al., 2001). These however become harmful when the atmospheric concentration of these gases alongside other lethal sources such as hydroflourocarbons (HFCs), perflourocarbons ( $\mathrm{PFC}$ ), chloroflourocarbons (CFCs), sulphurhexaflouride $\left(\mathrm{SF}_{6}\right)$, Nitrogen triflouride, triflouromethyl sulphur pentaflouride, carbon-monoxide $(\mathrm{CO})$, benzene 1,3 butadiene, lead $(\mathrm{Pb})$, polycyclic aromatic hydrocarbon $(\mathrm{PAH})$, fine particles $\left(\mathrm{PM}_{10}\right)$, halogenated ethers and other halocarbons (IPCC, 2006; Dawson et al., 2007; United Nations Environment Programme [UNEP], 2007; Li, 2009; Odjugo, 2011), largely released from various human activities increase. These gases deplete ozone layer, expose earth surface to more solar radiation and traps the outgoing heat within the surface-troposphere system. Anthropogenic activities that increase these gases in damaging quantity ranges from transportation, industrialization, urbanization, burning of fossil fuel, natural gas flaring, agricultural activities, water pollution, deforestation, change of land use, poor waste disposal, household and building related activities such as cooking, lighting, heating, cooling, etc (IPCC, 2007; Synnefa et al., 2007; UNEP, 2007; Nzeadibe Chukwuone Egbule, \& Agu, 2011; Odjugo, 2011; Otegbulu, Osagie, \& Afe, 2011; UN-Habitat, 2011).

\subsection{Urban Household Activities and Greenhouse Gas Emission}

In order to properly address the issue of global warming, interest has been placed by global communities and organizations on the pattern and quantum of GHG emanating from urban centres. As argued in UN-Habitat (2011), "urban areas-which are now home to more than half of the world's population-clearly have an important role to play in facilitating reduced emissions; yet the contribution of urban areas to emissions is often unclear". Towns and cities do not themselves emit GHGs. Rather, specific activities that take place within urban areas-and that are undertaken in different ways by people of different ages, genders and income groups-are the sources of these GHGs (UN-Habitat, 2011). GHG emission from building and household activities in urban centres has assumed a significant dimension because of the increasing number of people and activities that produce it daily. According to the UN-Habitat (2011) report, the proportion of human-induced GHG emissions resulting from cities could be between 40 and 70 percent using production-based figures and between 60 and 70 percent using consumption-based method. The report however noted that the main sources of GHG emissions from urban areas are related to the consumption of fossil fuels for energy supply mainly for electricity generation, transportation, energy use in commercial and residential buildings for lighting, cooking, space heating, and cooling; industrial production; and waste. The report further noted that emissions are affected by the need for heating and cooling, the behaviour of building occupants as well as the type of fuel used.

Buildings consume over $40 \%$ of global energy use and one-third of total GHG emission globally (UNEP, 2009). In most countries, energy use in the building sector represents about one-third of the total energy consumption (EIA, 2003) while residential building sector accounts for more than half of the electricity consumption in developing countries. In developed nations with cold climate, space heating consumes $60 \%$ of residential energy while other heating purposes like water heating consumes $18 \%$, refrigeration and cooking $6 \%$, lighting $3 \%$ and other uses 13\% (UNEP, 2007). In sub-Saharan Africa, the residential sector consumes as much as $56.2 \%$ of total energy consumed compared to the $2.2 \%$ consumed in the commercial and public sectors (UNEP, 2007). Energy supply especially in sub-Sahara Africa is largely depended on biomass and fossil fuel because of the poor access to electricity. Energy for many household activities such as lighting, cooking, heating, cooling and ventilation are derived from fossil fuel, wood, coal, electricity or a combination of these sources. According to Otegbulu et al. (2011), household activities are energy intensive with associated GHG emission but because most building occupants are ignorant of their environmental impact, these activities are carried out in improvident manners.

\subsection{Climate Change Impacts and Urban Vulnerability}

Climate change affects all spheres of human and natural environment. Different studies have shown the causes and effects of extreme weather conditions as they relate to climate change and confirmed the fact that the impacts are becoming more devastating (Awosika et al., 1992; Nyelong, 2004; Odjugo, 2000, 2007). Anthropogenic global warming have been found to be significantly responsible for climate change with diverse consequences such as sea-level rise, tropical cyclones, heavy precipitation, extreme heat, drought, hailstorm and fire outbreak with physical, economic, health and social impacts. Studies have explored the global distribution of potential arable land in terms of biophysical circumstances under current and future climate conditions (Xiao, 1997; Food and Agricultural Organisation of the United Nations FAO, 2000; Ramankutty et al., 2002) and have also discovered that climate change affect agricultural productivity and pastoral land availability (Zhang \& Cai, 2011), agricultural practice, farm size and land value (Sprenza \& Feres, 2010) residential transaction (Rita \& 
Man, 2009), while Hayoe et al. (2010) have looked into an integrated framework for quantifying and valuing climate change impacts on urban energy and infrastructure.

Urban centres are particularly vulnerable to climate change in that they are immobile (WBR, 2010). Such infrastructure as bridges, subway systems, buildings and road, the historic sense of place and rootedness of residents are critical attributes of cities. These however become liabilities where the local ecosystems are unable to adapt to the climate-induced changes (WBR, 2010). The IPCC report states that climate change is almost certain to affect human settlements, large and small in a variety of significant ways (Willbanks et al., 2007). The report further stated that climate change is likely to exacerbate many of the risks faced by low-income urban residents and that poor communities can be especially vulnerable especially those concentrated in relatively high-risk areas. Urban areas in low and middle income nations already house a large percentage of the people and economic activities most at risk from climate change (Dodman, 2009). The types of change and possible impacts on urban areas are summarised by Willbanks et al. (2007) as changes in means, changes in extreme and changes in exposure and are presented in the Table 1 below.

Table 1. Climate change impacts on urban areas

\begin{tabular}{|c|c|}
\hline Change in climate & Possible impact on urban areas \\
\hline \multicolumn{2}{|l|}{ Changes in means } \\
\hline \multirow[t]{3}{*}{ Temperature } & -Increased energy demands for heating/cooling \\
\hline & -Worsening of air quality \\
\hline & -Exaggerated by urban heat islands \\
\hline \multirow[t]{4}{*}{ Precipitation } & -Increased risk of flooding \\
\hline & -Increased risk of landslides \\
\hline & -Distress migration from rural areas \\
\hline & -Interruption of food supply networks \\
\hline \multirow[t]{3}{*}{ Sea-level rise } & -Coastal flooding \\
\hline & -Reduced income from agriculture and tourism \\
\hline & -Salinisation of water sources \\
\hline \multicolumn{2}{|l|}{ Changes in extremes } \\
\hline Extreme rainfall/ & -More intense flooding \\
\hline \multirow[t]{3}{*}{ Tropical Cyclones } & -Higher risk of landslides \\
\hline & -Distruption to livelihoods and city economies \\
\hline & -Damage to homes and businesses \\
\hline \multirow[t]{4}{*}{ Drought } & -Water shortages \\
\hline & -Higher food prices \\
\hline & -Disruption of hydro-electricity \\
\hline & -Distress migration from rural areas \\
\hline Heat or cold waves & -Short-term increase in energy demands for heating/cooling \\
\hline \multirow[t]{2}{*}{ Abrupt climate change } & $\begin{array}{l}\text {-Possible significant impacts from rapid and extreme sea-level } \\
\text { rise }\end{array}$ \\
\hline & $\begin{array}{l}\text {-Possible significant impacts from rapid and extreme temperature } \\
\text { change }\end{array}$ \\
\hline \multicolumn{2}{|l|}{ Change in exposure } \\
\hline Population movements & -Movement from stressed rural habitats \\
\hline Biological Changes & -Extended vector habitats \\
\hline
\end{tabular}

Adapted from Willbanks et al. (2007). 


\subsection{Urban Residents' Awareness and Understanding of Climate Change}

The UN-Habitat (2011) Report concludes that with increasing urbanization, understanding the impacts of climate change on the urban environment will become even more important. The manner at which slums grow and the handling of several household activities in developing countries does not only depict weak governance but also a people that lack proper understanding of implications of their activities on the environment. Otegbulu et al. (2011) observed that a variety of indoor activities like heating, cooking, cooling, lighting and other electrical activities are energy intensive with associated GHG emission but because of ignorant of their environmental impact, these activities are carried out in improvident manners. The attitudes of urban residents can be attributed to their level of understanding of the phenomenon. Studies have also revealed that there are some misconception and misunderstanding that people hold about climate change in terms of causality, consequences and cures (Boyes \& Stanisstreet, 1998, 1992; Dove, 1996; Rye, Rubba, \& Wiesenmajer, 1997). These misconceptions according to Aladag and Ugurlu (2009) are probably due to, among other things, the complexity of the science involved, the uncertainties and controversies surrounding them. According to Ekpoh and Ekpoh (2011), climate change specialists have repeatedly pointed out that a solution to climate change problem will require climate change awareness and its proper understanding.

Arresting the menace of climate change therefore requires that everyone is adequately informed about the causes, contributors, consequences and control. Global concern regarding the devastating impact of climate change has emphasized the need for creating awareness and building community capacity for adaptation strategies to mitigate the effects of climate change (Adger, 2003; IPCC, 2007; Ekpoh \& Ekpoh, 2011). Otegbulu et al. (2011) investigates the contribution of building and household activities in Lagos State to GHG emission and concludes that household could trigger climate change. Nzeadibe et al. (2011) examines climate change awareness and adaptation of farmers in the Niger Delta of Nigeria and concludes that this is generally low. Ekpoh and Ekpoh (2011) also examine climate change awareness among secondary school teachers in Calabar municipality and discovered that the knowledge is very low and that access to such information is poor. Academic efforts toward public sensitization with primary focus on urban populace that are directly concerned with greenhouse gas emission from household activities appear inadequate. This study thus examines the level of awareness of urban residents to household activities as a significant source of greenhouse gas emission and proffer ways by which this can be improved.

\section{The Study Area}

Lagos State is widely acknowledged as the most populous urban centre in Africa, the second fastest growing city in Africa and seventh fastest in the world (Otegbulu et al., 2011). It is among the ten most populous urban centres around the world and projected to be the third in 2015 (UN, 1999 cited in Abiodun, Olaleye, Dokia \& Odunaiya, 2011). With a territorial land area of 356,861 hectares (3,577 square kilometres), Lagos State is made up of five administrative divisions, namely Lagos (Eko), Ikeja, Ikorodu, Epe and Badagry and further divided into 20 local government areas and 37 local council development areas (Lagosstateonline.com). It has a population figure of 9,013,534 (National Population Commission [NPC], 2006) and population growth rate estimated at about 275,000 persons per annum. Lagos Metropolitan area comprises sixteen local government areas in three administrative divisions and about $85 \%$ of the States' population. It covers only $37 \%$ of the land mass giving rise to average population density of about 20,000 persons per square km (Wikipedia). The local government areas that are not part of Lagos Metropolitan Area are Badagry, Ikorodu, Ibeju-Lekki and Epe in Badagry, Ikorodu and Epe divisions.

\subsection{Research Methods and Study Population}

This study focuses on residents in Lagos Metropolitan Area. The map of the local governments in Lagos Metropolitan Area is as shown in Figure 1. One local government area each with highest population was selected from each of the three administrative divisions that make up the Metropolitan Lagos. These are Alimosho, Surulere and Ajeromi-Ifelodun local government areas. The population for this study therefore is the 2,465,794 adult residents of the selected local governments which represents $27.36 \%$ of the total population of Lagos State (NPC, 2006). A total of 200 households were further selected from each of the three local governments across five different types of houses on quota basis. The types of houses include detached/semi-detached houses, detached bungalows and multi-tenanted such as tenement buildings, block of flats and block of single room and palour apartments. Vital issues addressed in the questionnaires borders mainly on residents' awareness and understanding of the causes, contributors and consequences of climate change and particularly, household activities as a significant source of greenhouse gas emission. Primary data for the study were collected with questionnaires administered on 600 households. However the researchers were able to retrieve only 578 properly 
completed questionnaires which are subsequently used for the analysis. Descriptive statistical tools such as tables, frequencies, percentages and charts are subsequently used to present the result. Analysis of the data collected entailed the use of percentages and frequencies. The results are presented using charts and tables.

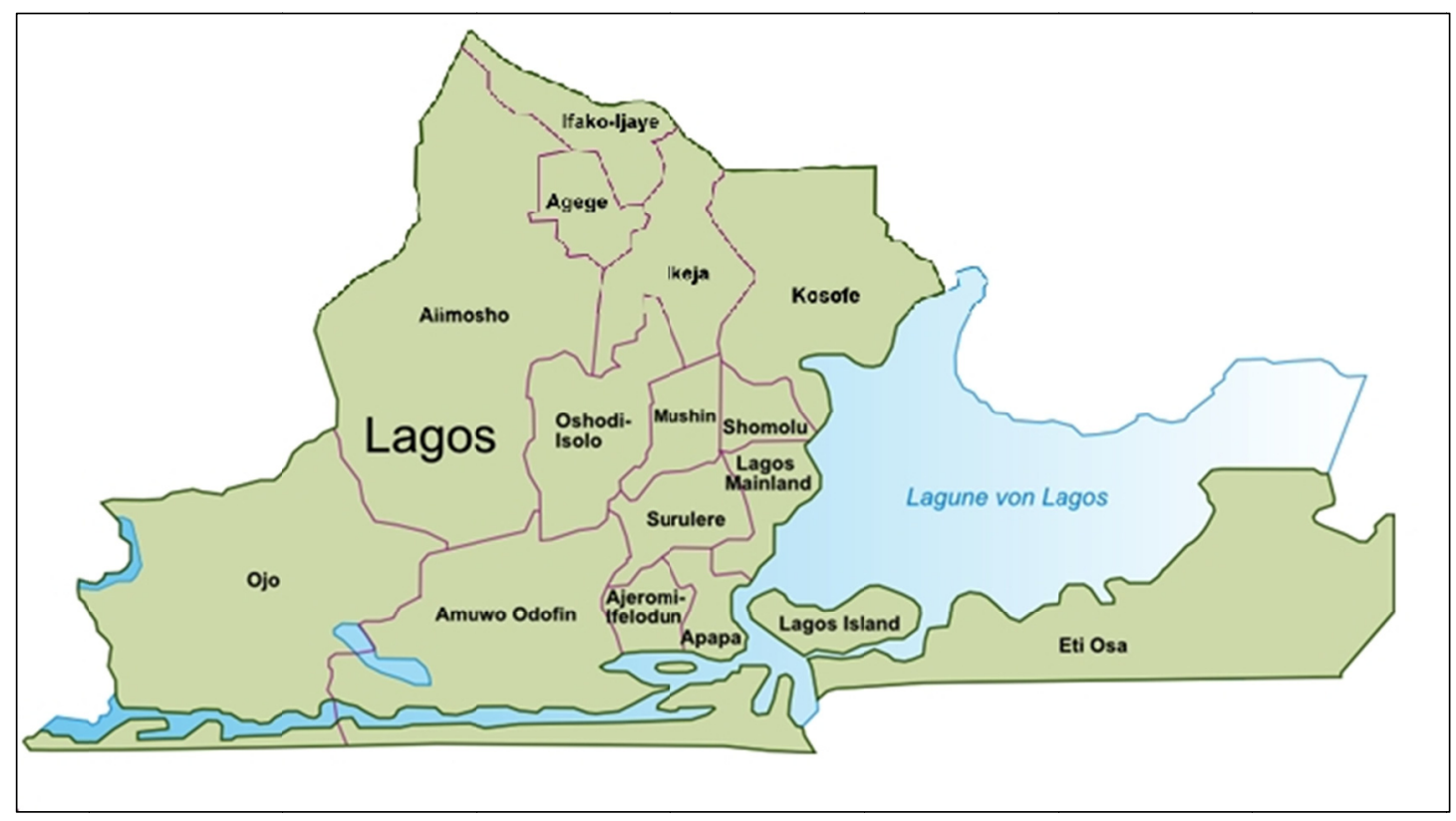

Figure 1. Map of the local government areas within lagos metropolis

Source: google.com.

\section{Result and Discussion}

\subsection{Response Rate and Residency Period of Respondents in Lagos State}

The spread and rate of response as indicated in Table 2 shows that out of the 600 questionnaires distributed $578(96.33 \%)$ were properly completed and returned. The table also shows the period that each of the households has lived in Lagos State though not necessarily in their present locations. Using percentages, the table shows that 249 households have lived in Lagos State for maximum of 15 years and 213 households have been residents in the state between 15 years and 30 years while 116 households have been residents in the State for over 30 years. It is therefore presumed that the response rate is significant enough and that the information provided by the residents emanate from their experience and/or observations of weather events over the years and therefore presumed reliable.

Table 2. Response rate and period of residence in Lagos State

\begin{tabular}{lccccc}
\hline \multicolumn{2}{c}{ Response rate } & \multicolumn{3}{c}{ Period of residency } \\
\hline LGAs & Returned & Not Returned & $\begin{array}{c}\text { Less than 15 } \\
\text { years }\end{array}$ & $\begin{array}{c}\text { Between 15 and 30 } \\
\text { years }\end{array}$ & $\begin{array}{c}\text { More than 30 } \\
\text { years }\end{array}$ \\
\hline Alimosho & 194 & 6 & 100 & 71 & 23 \\
Surulere & 193 & 7 & 71 & 66 & 56 \\
Ajeromi-Ifelodun & 191 & 9 & 78 & 76 & 37 \\
Total & 578 & 22 & 249 & 213 & 116 \\
Percentage & $96.33 \%$ & $3.67 \%$ & $43.08 \%$ & $36.85 \%$ & $20.07 \%$ \\
\hline
\end{tabular}

Source: Authors' Field Survey, 2012. 


\subsection{Household Size and Educational Qualifications}

The type of houses and size of households are also covered in the survey exercise. Questionnaires are administered to 600 households in a total number of 375 different houses comprising 60 units of detached/semi-detached houses, 45 units of detached bungalows, 30 units of storey tenement buildings, 120 units of $2 / 3$ bedroom flats and 120 units of one-room apartments selected across the three local government areas. Table 3 shows that 294 households have between 1-4 persons, 211 households have between 5-7 persons while 73 households have more than 7 persons per household respectively. The type of house occupied by a household signifies the level of income while household size indicates the intensity of energy consumption. The table further shows that 39 of respondents possess 6years of basic education, 122 possess 12 years of secondary education, 321 posses between 14-17 years of diploma and first degree while 96 of total respondents have beyond 17 years of second and third degrees respectively. By implication, all the respondents are deemed literate enough to provide answers to the information required based on their level of education. Further examination of data also shows the occupation and management style of houses surveyed and shows that 328 units of the houses surveyed are rented, 42 units are co-occupied with the tenants, 322 units are managed by professional property managers, while the remaining 53 units are managed by the owners or quack agents.

Table 3. Number of persons per household and level of education of respondents

\begin{tabular}{lccccccc}
\hline \multicolumn{1}{c}{ LGAs } & \multicolumn{2}{c}{$\begin{array}{c}\text { Number of persons per } \\
\text { household }\end{array}$} & \multicolumn{4}{c}{ Respondents' level of education } \\
\hline & $1-4$ & $5-7$ & $7-9$ & Primary & Secondary & $\begin{array}{c}\text { Diploma/ } 1^{\text {st }} \\
\text { Degree }\end{array}$ & $\begin{array}{c}2^{\text {nd }} / 3^{\text {rd }} \\
\text { Degree }\end{array}$ \\
\hline Alimosho & 92 & 47 & 26 & 18 & 61 & 79 & 36 \\
Surulere & 103 & 75 & 27 & 9 & 28 & 123 & 33 \\
Ajeromi-Ifelodun & 99 & 89 & 21 & 12 & 33 & 119 & 27 \\
Total & 294 & 211 & 73 & 39 & 122 & 321 & 96 \\
Percentage & $43 \%$ & $37 \%$ & $13 \%$ & $14 \%$ & $21 \%$ & $56 \%$ & $17 \%$ \\
\hline
\end{tabular}

Source: Authors' Field Survey 2012.

\subsection{Respondents' Understanding of Climate Change}

Table 4 presents respondents' understandings of climate change and show that out of the 578 respondents, only 550 respondents indicate awareness and that the extent of their awareness varies significantly. Furthermore, the distributions of opinion as presented in the table shows that $50 \%$ and above of respondents consider climate change in terms of change in weather, extended rainy season, extended dry season, heavy rainfall, excessive sunshine and excessive heat. Less than $50 \%$ however sees it in terms of reduced agricultural productivity or ozone layer depletion. By implication, everyone that indicated awareness of climate change express their understanding of the phenomenon in term of some kind of unusual occurrence or observations of weather events.

Table 4. Respondents' understanding of climate change

\begin{tabular}{lcccccccc}
\hline LGAs & $\begin{array}{c}\text { Change } \\
\text { in } \\
\text { weather }\end{array}$ & $\begin{array}{c}\text { Extended } \\
\text { rainy } \\
\text { season }\end{array}$ & $\begin{array}{c}\text { Extended } \\
\text { dry } \\
\text { season }\end{array}$ & $\begin{array}{c}\text { Heavy } \\
\text { rainfall }\end{array}$ & $\begin{array}{c}\text { Excessive } \\
\text { sunshine }\end{array}$ & $\begin{array}{c}\text { Excessive } \\
\text { heat }\end{array}$ & $\begin{array}{c}\text { Reduced } \\
\text { agricultural } \\
\text { productivity }\end{array}$ & $\begin{array}{c}\text { Ozone } \\
\text { layer } \\
\text { depletion }\end{array}$ \\
\hline Alimosho & 157 & 123 & 118 & 122 & 90 & 108 & 66 & 41 \\
Surulere & 148 & 126 & 123 & 124 & 85 & 103 & 63 & 35 \\
Ajeromi-Ifelodun & 145 & 135 & 126 & 129 & 100 & 114 & 68 & 32 \\
Total & 450 & 384 & 367 & 375 & 275 & 325 & 197 & 108 \\
Percentage (\%) & $81.82 \%$ & $69.82 \%$ & $66.73 \%$ & $66.18 \%$ & $50 \%$ & $59.09 \%$ & $35.82 \%$ & $16.64 \%$ \\
\hline
\end{tabular}

Source: Authors field survey 2012 (Multiple choice responses). 


\subsection{Respondents' Awareness of the Causes of Climate Change}

Table 5 illustrate respondents' awareness of the causes of climate change. The analysis shows that awareness of the various causes of climate change is generally below average. It was also revealed that more people still see climate change as a result of natural causes and industrialization as indicated by $264(45.68 \%)$ and $211(38.36 \%)$ of the total respondents respectively. Despite this, poor waste disposal and household activities have the lowest awareness rate with only $29(5.27 \%)$ and $28(5.29 \%)$ respondents indicating knowledge of their possible contribution to climate change.

Table 5. Respondents' awareness of the causes of climate change

\begin{tabular}{|c|c|c|c|c|c|}
\hline Causes/LGAs & Alimosho & Surulere & Ajeromi-Ifelodun & Total & $\%$ \\
\hline Natural causes & 92 & 90 & 82 & 264 & $45.68 \%$ \\
\hline Industrialization & 68 & 70 & 73 & 211 & $38.36 \%$ \\
\hline Urbanization & 47 & 51 & 55 & 153 & $27.82 \%$ \\
\hline Transportation & 54 & 59 & 61 & 174 & $31.64 \%$ \\
\hline Fuel combustion & 60 & 63 & 61 & 184 & $31.83 \%$ \\
\hline Gas Flaring & 55 & 59 & 61 & 175 & $31.82 \%$ \\
\hline Agricultural activities & 41 & 37 & 40 & 118 & $21.45 \%$ \\
\hline Water pollution & 50 & 53 & 57 & 160 & $29.09 \%$ \\
\hline Deforestation & 59 & 63 & 62 & 184 & $33.45 \%$ \\
\hline Change of land use & 38 & 43 & 44 & 125 & $22.73 \%$ \\
\hline Poor waste disposal & 31 & 35 & 32 & 29 & $5.27 \%$ \\
\hline $\begin{array}{l}\text { Household activities (e.g. } \\
\text { cooking, lighting, heating, } \\
\text { cooling, etc) }\end{array}$ & 11 & 13 & 18 & 28 & $5.09 \%$ \\
\hline
\end{tabular}

Source: Authors' Field Survey 2012 (Multiple choice responses).

\subsection{Respondents' Awareness of Consequences of Climate Change}

Information about respondents' awareness of the consequences of climate change was also collected and examined. The 550 respondents that showed awareness of climate change further indicated their knowledge of the consequences of climate change and it shows that that frequent and severe flooding rank highest with $448(81.46 \%)$ respondents followed by heavy and excessive rainfall with $379(68.91 \%)$ respondents, frequent ocean surge with $351(63.82 \%)$ respondents and damage to property and infrastructure with $320(58.19 \%)$ respondents. Consequences such as shortage of quality water, aggravated poverty, poor air quality among others rank low on the table favoured by $29(5.27 \%), 68(12.36 \%)$ and $77(14.00 \%)$ respondents respectively. By implication, the respondents that are aware of climate change incidence were also able to point out the consequences based on their level of knowledge about the phenomenon. 


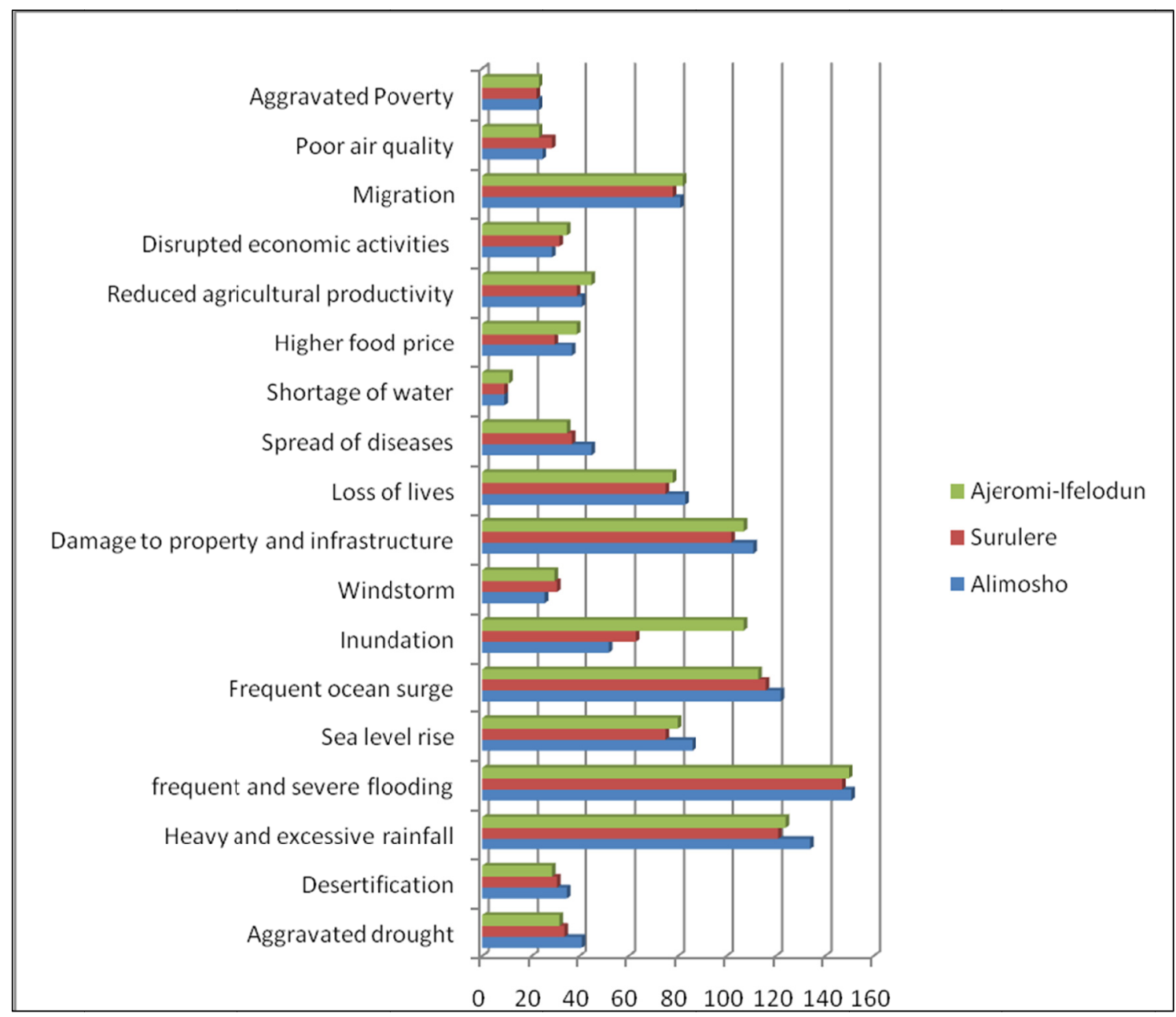

Figure 2. Residents' awareness of consequences of climate change

\subsection{Household Activities and Appliances Usage}

Information was also obtained from respondents concerning household activities, sources of energy, appliances usage and pattern of energy consumption. Table 6 shows that households require energy for various domestic activities such as cooking, heating, lighting, cooling and laundry. In order to meet the energy requirement, households rely on electric power supply, fossil fuel (petrol, kerosene and diesel), natural gas or biomass (coal, wood). Some households combine different sources to ensure smooth running of domestic activities on daily basis. Moreover, enquiries were made into the use of insecticide and discovered that that 504 representing $87.20 \%$ respondents indicate the use of insecticide while 74 representing $12.80 \%$ of the respondents do not use insecticide. This signifies that the use of insecticide is high among urban residents with direct impact on atmospheric greenhouse gas concentration. Consequently, the manner of use of household appliances and energy consumption for various household activities clearly indicate residents' lack of knowledge of the impact of these activities on the concentration of atmospheric greenhouse gases. 
Table 6. Household activities and use of household appliances

\begin{tabular}{|c|c|c|c|c|c|c|c|c|c|c|c|c|}
\hline \multirow{3}{*}{$\begin{array}{l}\text { Purpose/Activities } \\
\text { Appliances }\end{array}$} & \multicolumn{12}{|c|}{ No of household and hour of usage per day } \\
\hline & \multicolumn{2}{|c|}{ Cooking } & \multicolumn{2}{|c|}{ Lighting } & \multicolumn{2}{|c|}{ Heating } & \multicolumn{2}{|c|}{ Cooling } & \multicolumn{2}{|c|}{ Laundry } & \multicolumn{2}{|c|}{ Insect control } \\
\hline & $\mathrm{x}$ & $\mathrm{y}$ & $\mathrm{x}$ & $\mathrm{y}$ & $\mathrm{x}$ & $\mathrm{y}$ & $\mathrm{x}$ & $\mathrm{y}$ & $\mathrm{x}$ & $\mathrm{y}$ & Yes & No \\
\hline Generator & 158 & 8 & 542 & 14 & - & - & 256 & 10 & - & - & - & - \\
\hline Gas cooker & 267 & 6 & - & - & - & - & - & - & - & - & - & - \\
\hline Electric cooker & 519 & 6 & - & - & - & - & - & - & - & - & - & - \\
\hline Kerosene Stove & 578 & 6 & - & - & - & - & - & - & - & - & - & - \\
\hline Charcoal \& wood & 308 & 4 & & & & & & & & & - & - \\
\hline Microwave & 426 & 4 & - & - & 426 & 3 & - & - & - & - & - & - \\
\hline Ring Boiler & - & - & - & - & 497 & 4 & - & - & - & - & - & - \\
\hline Bath heater & - & - & - & - & 215 & 3 & - & - & - & - & - & - \\
\hline Air Conditioner & - & - & - & - & - & - & 427 & 10 & - & - & - & - \\
\hline Refrigerator & - & - & - & - & - & - & 540 & 22 & & & - & - \\
\hline Laundry engine & - & - & - & - & - & - & - & - & 314 & 4 & - & - \\
\hline Electric iron & - & - & - & - & - & - & - & - & 578 & 2 & - & - \\
\hline Coal iron & - & - & - & - & - & - & - & - & 154 & 2 & - & - \\
\hline Incandescent bulb & - & - & 578 & 12 & - & - & - & - & - & - & - & - \\
\hline Fluorescent & - & - & 428 & 12 & - & - & - & - & - & - & - & - \\
\hline Candle stick & - & - & 237 & 6 & - & - & - & - & - & - & - & - \\
\hline Kerosene lamp & - & - & 283 & 9 & - & - & - & - & - & - & - & - \\
\hline Gas lamp & - & - & 167 & 9 & - & - & - & - & - & - & - & - \\
\hline Insecticide & - & - & - & - & - & - & - & - & - & - & 504 & 74 \\
\hline
\end{tabular}

Source: Authors' Field Survey 2012 (Multiple choice responses).

$\mathrm{x}$ represents the number of household.

$\mathrm{y}$ represents the average hours of daily use.

\subsection{Respondents' Sources of Information on Climate Change}

In the final analysis, respondents were asked to indicate their source of awareness on climate change. Table 15 shows that broadcast, print and web media are the major sources of information on climate change as indicated by more than $58.18 \%, 46.91 \%$ and $34.18 \%$ of the respondents. Other sources such as educational workshop, research publications, civil societies, property managers and worship places have not been adequately explored and utilised in sensitizing the public as reflected in the proportion of respondents that indicates awareness via these media. Response from residents indicates that property occupants are barely informed by the professional property managers about climate change. 
Table 7. Respondents' sources of information on climate change

\begin{tabular}{lccccc}
\hline Sources & Alimosho & Surulere & Ajeromi-Ifelodun & Total & Percentage \\
\hline Broadcast media e.g.TV, radio & 115 & 98 & 107 & 320 & $58.18 \%$ \\
Print media e.g. newspaper, fact & 96 & 83 & 79 & 258 & $46.91 \%$ \\
bronchures, bills and leaflets & & & & & \\
Electronic e.g. Internet & 58 & 67 & 63 & 188 & $34.18 \%$ \\
Special educational workshop, & 24 & 36 & 33 & 93 & $16.91 \%$ \\
seminars and conferences & & & & & \\
Research publications & 31 & 19 & 24 & 74 & $13.45 \%$ \\
Public lectures by LGAs & 19 & 17 & 20 & 56 & $10.18 \%$ \\
Civil societies/organization & 23 & 24 & 22 & 69 & $12.55 \%$ \\
Property owners/managing agent & - & - & - & - & - \\
Professional Property Managers & 6 & 13 & 9 & 28 & $5.09 \%$ \\
Worship centres & 4 & 7 & 9 & 20 & $3.64 \%$ \\
Others (not mentioned) & - & - & & - & - \\
\hline
\end{tabular}

Source: Authors' Field Survey 2012 (Multiple choice response).

\section{Conclusion and Recommendations}

This study has examined largely the awareness and understanding of urban population about the causes, contributors and consequences of climate change and show that despite the fact that majority indicate various level of awareness, their understanding of the phenomenon and consequences vary significantly while the knowledge of the causes is generally low. The level of energy demand for household activities in urban centres is substantially augmented with other sources such as petrol, kerosene, diesel, coal and wood due to erratic electricity supply. With increasing urbanization and population growth, energy consumption and greenhouse gas emission will increase in developing countries. Of more concern however is that majority of urban population still attribute climate change to natural causes and industrialization as shown in Table 5 and could not understand how household activities contribute to greenhouse gas emission and causes climate change.

In order to control household energy consumption pattern in developing countries, proper sensitization of urban residents on causes of climate change, particularly the role of household activities in greenhouse gas emission is very important. Majority of the respondents identify their sources of information as television, radio and newspapers (Table 7). However, it is suggested that climate change education be incorporated in basic, secondary and tertiary school curricula. Moreover, majority of urban residents are living in rented apartment that are either managed by the owner or (professional or quack) agents. The terms of lease agreements most times are concerned with the protection of the subject property from abuse, arbitrary alterations, maintenance and repair as well as rent consideration. Estate surveyors and valuers are deemed to have sufficient basic knowledge about climate change (Otegbulu et al., 2011) and therefore a veritable tool for sensitising urban residents particularly on greenhouse gas emission emanating from household activities. Also advocated is the use of public lectures, seminars organised at local government level as well as sensitization in places of worship. It is anticipated that a lot could be achieved in reducing greenhouse gas emission from household activities in future provided proper sensitization begins now.

Aside raising urban residents' awareness, there is the need for government of developing and less developed countries to invest in the development and production of economical and environment-friendly alternative sources of household energy such as biomass, natural gas, wind and solar energy in quantity that meet energy demand of the developing countries as this is the only proviso for effective action against climate change. Other areas such as adaptive capacity of urban residents to climate change are open up for further research in this study. 


\section{References}

Abiodun, O. E., Olaleye, J. B., Dokia, A. N., \& Odunaiya, A. K. (2011). Land use change analysis in Lagos State, Nigeria, from 1984 to 2005. FIG Working week 2011, Bridging the Gap between Cultures Marrakech, Morocco, 18-22 May 2011; TS09C - Spatial Information Processing II, 5142.

Adeniji, G., \& Ogundiji, B. (2009). Climate adaptation in Nigerian cities; Regularising informal and illegal settlements in Ibadan. A paper presentation for the World Bank's 2009 Urban Symposium, June 28-30, Marseille, France.

Adger, W. N. (2003). Social Capital, Collective Action, and Adaptation to Climate Change. Economic Geography, 79(4), 387-404.

Aladag, E., \& Ugurlu, N. B. (2009). Global climate change education in Turkey. Conference Paper Turkey. Retrieved from http://www.herodotnet/conferences/AJVALIK/ papers/educ

Awosika, L. F., French, C. T., Nicholas, R. T., \& Ibe, C. E. (1992). The impact of sea level rise on the coastline of Nigeria. In J. O'Callahan (Ed.), Global Climate and the Rising Challenges of the Sea. Proceedings of the IPCC workshop at Mongarine Island, Venezuala 9-13 March, 1992.

Balk, D., Pozzi, F., Yetman, G., Deichmann, U., \& Nelson, A. (2004). The distribution of people and the dimension of place: Methodologies to improve the global estimation of urban extents, DRAFT Working Paper, Earth Institute's Centre for International Earth Science Information Network, Columbia University. Retrieved from http://sedac.ciesin.columbia.edu/gpw/docs/UR_paper_webdraft1.pdf

Boyes, E., \& Stanisstreet, M. (1992). Students' perception of global warming. International Journal of Environmental Studies, 4(4), 287-300. http://dx.doi.org/10.1080/00207239208710804

Boyes, E., \& Stanisstreet, M. (1998). High school students' perception of how global environmental effects might cause skin cancer. Journal of Environmental Education, 29(2), 31-36. http://dx.doi.org/10.1080/00958969809599110

Dodman, D. (2009). Urban density and climate change. An analytical review of the Interaction between urban growth changes and environmental changes by united nations population fund (UNFPA).

Dawson, R. J., Hall, J. W., Barr, S., Batty, M., Bristow, A., Carney, S., ... Walsh, C. (2006). A blueprint for the integrated assessment of climate change in cities (Draft, Version 1.2). Tyndall Working Paper 104.

Dove, J. (1996). Student teachers' understanding of Green-house effect, ozone layer depletion and acid rain. Environmental Education Research, 2(1), 89-100. http://dx.doi.org/10.1080/1350462960020108

Ekpoh, U. I., \& Ekpoh, I. J. (2011). Assessing the level of climate change awareness among secondary school teachers in calabar municipality, Nigeria: implication for management effectiveness. International Journal of Humanities and Social Science, 1(3), 106-110. Retrieved from www.ijhssnet.com

Energy Information Administration (EIA), International Energy Annual. (2003). Retrieved from http://www.eia.doe.gov/iea/

FAO. (2000). Land resource potential and constraints at regional and country levels (Rome: Food and Agriculture Organization of the United Nations).

Hayhoe, K., Robson, M., Rogula, J., Auffhammer, M., Miller, N., VanDorn, Y., \& Wuebbles, D. (2010). An integrated framework for quantifying and valuing climate change impacts on urban energy and infrastructure: A Chicago Case Study. Journal of Great Lakes Research, 36(sp2), 94-105. http://dx.doi.org/10.1016/j.jglr.2010.03.011

International Energy Agency (IEA). (2007). Climate policy uncertainty and investment risk. The International Energy Agency, Paris.

International Energy Agency (IEA). (2008). World Energy Outlook 2008. Paris: International Energy Agency.

Intergovernmental Panel on Climate Change. (2001). Climate Change 2001: Impacts, Adaptation, and Vulnerability: Contribution of Working Group II to the Third Assessment Report of the Intergovernmental Panel on Climate Change. Cambridge University Press.

IPCC. (2006). Intergovernmental Panel on Climate Change Guidelines for National Greenhouse Gas Inventories. S. Eggleston, L. Buendia,

Intergovernmental Panel on Climate Change, Climate Change. (2007). Mitigation of Climate Change, Contribution of Working Group III to the Fourth Assessment Report of the Intergovernmental Panel on 
Climate Change. Cambridge, United Kingdom: Cambridge University Press and New York, NY, USA, 2007.

Juliana, S., \& Jose, F. (2010). Evaluating the long-term effects of global climate change on Brazilian Agriculture according to farm size. Working Paper Series No. 2010 - WP19. Retrieved from www.laceep.org

Li, Rita Yi Man. (2009). The impact of climate change on residential transactions in Hong Kong. Journal of the Built \& Human Environment Review, 2(1).

Madzwamuse, M. (2010). Climate Governance in Africa: Adaptation Strategy and Institutions. A synthesis report submitted to Heinrich Böll Stiftung.

Mills, E., Lecomte, E., \& Peara, A. (2001). U.S. Insurance Industry Perspectives on Global Climate Change. Retrieved from http://eetd.lbl.gov/insurance

Miwa, K., Ngara, T., \& Tanabe, K. (2006). Institute for Global Environmental Strategies (IGES) Publishers, Kanagawa Japan. Retrieved from www.ipcc-nggip.iges.or.jp/ public/2006gl/index.html

Nyelong, P. N. (2004). Global warming and global waters. Journal of Energy and Environment, 17(1), 79-90.

Nzeadibe, T. C., Chukwuone, N. A., Egbule, C. L., \& Agu, V. C. (2011). Climate change awareness and adaptation in the Niger Delta Region of Nigeria: Working Paper Series No. 57 Published by the African Technology Policy Studies Network. Nairobi Kenya.

Odjugo, P. A. O. (2007). The impact of climate change on water resources; global and regional analysis. The Indonesian Journal of Geography, 39, 23-41.

Odjugo, P. A. O. (2000). The impacts of global warming on climate change and extreme weather conditions: Global and regional evidences. Asia Pacific Journal on Environment and Development, 7, 53-70.

Odjugo, P. A. O. (2011). Climate change and global warming: The Nigerian perspective. Journal of Sustainable Development and Environmental Protection, 1(1), 6-17.

Otegbulu, A. C., Osagie, J. U., \& Afe, Y. O. (2011). The built environment perspective of climate change - A focus on household activities in Lagos Metropolis. Journal of Sustainable Development, 4(5), 174-187. http://dx.doi.org/10.5539/jsd.v4n4p174

Ramankutty, N., Foley, J. A., Norman, J., \& McSweeney, K. (2002). The global distribution of cultivable lands: current patterns and sensitivity to possible climate change. Global Ecology and Biogeography, 11(5), 377-392. http://dx.doi.org/10.1046/j.1466-822x.2002.00294.x

Rye, J., Rubba, P., \& Wiesenmajer, R. (1997). An investigation of middle school students' alternative conceptions of global warming. International Journal of Science Education, 19(15), 527-551. http://dx.doi.org/10.1080/0950069970190503

Synnefa, A., Santamouris, M., \& Akbari, H. (2007). Estimating the effect of using cool coatings on energy loads and thermal comfort in residential buildings in various climatic conditions. Journal of Energy and Building, 39, 1167-1174. http://dx.doi.org/10.1016/j.enbuild.2007.01.004

United Nations. (2001). The State of the World's Cities. United Nations Centre for Human Settlements, Nairobi, Kenya.

UN. (2004a). State of the World's Cities 2004/2005 - Globalisation and Urban Culture. New York: United Nations Publications.

UN. (2004b). World Urbanisation Prospects: The 2003 Revision. New York: United Nations Publications.

United Nations Environment Programme-UNEP. (2007). Buildings and climate change: Status, challenges and opportunities. Paris: UNEP DTIE Sustainable Consumption \& Production Branch.

United Nations Environment Programme-UNEP. (2009). Buildings and climate change: Summary for decision-makers. Paris: UNEP DTIE Sustainable Consumption \& Production Branch.

United Nations Human Settlements Programme; UN-Habitat. (2011). Cities and Climate Change. Global Report on Human Settlements, Earthscan, London.

WBR. (2010). Cities and Climate Change: An Urgent Agenda. A Report of the International Bank for Reconstruction and Development and World Bank 2010.

Willbanks, T., Romero, L. P., Bao, M., Berkhout, F., Cairncross, S., ... Zapata-Marti, R. (2007). Industry, Settlement and Society. In M. Parry, O. Canziani, J. Palutikof, P. van der linden, \& C. Hanson (Eds.), 
Climate Change 2007: Impacts, Adaptation and Vulnerability. Contribution of Working Group II to the Fourth Assessment Report of the Intergovernmental Panel on Climate Change. Cambridge: Cambridge University Press.

Xiao, X. (1997). Transient climate change and potential croplands of the world in the 21 st century Report \#18 (Cambridge, MA: Massachusetts Institute of Technology).

Xiao, Z. \& Cai, X. M. (2011). Climate Change Impacts on Global Agricultural Land Availability. Environmental Research Letters. http://dx.doi.org/10.1088/1748-9326/6/1/014014

http://lagosstateonline.com/govhistory

http://en.wikipedia.org/wiki/Lagos

http://www.google.com/imgres?imgurl=http://www.nigerianmuse.com/images/Lagos_State_LGs

http://www.nigeriavillagesquare.com/newsflash/npc-releases-2006-population-figures 